\title{
The Everyday Information Experience of Street-Level Wayfinding: A Critical Look
}

\section{Introduction}

In the following paper I look at the information practice of wayfinding - the means by which people orient in and navigate through spaces. In contemporary information conditions of networked mobility, wayfinding is often associated with 'asking' Google Maps to locate where something is and how to get there. Google Maps is the most popular application for mobile devices with over 1 billion people putting it to work every month. Despite this frequency, there is little information available on how Google Maps is used. As technology writer Andrew J. Hawkins proclaims (2017), "we just need the directions, the right subway route, or the name of that good sushi place." What is happening in these moments when one needs directions? And more specifically, to paraphrase Sarah Sharma (2012), whose routes become reified by Google Maps? I argue that the imaginary of the Google Maps 'user' is more than simply an archetype but an orientation within a spatialization of information that are made evident in acts of everyday wayfinding.

\section{Framework}

The concept of wayfinding has been an important concept in museums and libraries as a means to think about visitor experience (Mandel 2018, 2013, 2012, 2010; Falk \& Dierking 2016; Bjornborn 2008). Lauren Mandel's research looks at the type of informational media used in the process of wayfinding in libraries. The focus is on forms of sense-making within an institutional space where many types of lived experiences converge. Mandel's research focuses on wayfinding in the service of the library infrastructures. My research goes outside the walls of the library and to the thresholds of formal and informal information spaces. What I am most interested in is street-level perceptions of spatial orientations and wayfinding within contemporary conditions of digital mapping and locative information technologies.

To frame my critical approach to contemporary wayfinding practices, I draw from an interdisciplinary body of scholarship in critical information and media studies that attend to themes of everyday information seeking and sense-making (Savolainen 1995, 2008; Dervin 1983, 2003), navigating information spaces (Mandel 2018, 2010; Arthurs \& Passini 1992), mapping urban media environments (Mattern 2015, 2017), the affects of dominant temporal and spatial arrangements (Sharma 2012, 2014; Ahmed 2008, 2010; Tuck \& McKenzie 2015; Massey 2005), and the politics of Google' (Noble 2018, 2011; Roberts 2018; Noble \& Roberts 2015).

\section{Methods}

To think through street-level wayfinding I designed an exploratory research project that focuses on the street, a site where people, infrastructures, and technologies overlap and a variety of sidewalk mobilities are enacted (Cresswell 2006, 2011; Hannam, Sheller, \& Urry 2006; Urry 2007). In the streets of Toronto (Tkaronto), New York (Mannahatta), Amsterdam, and London, I approached passers-by and asked for directions, with the follow up request that the informant draw their directions for me, using paper and pen I provided. I based my research design off a conceptual art project from the early 1960s by conceptual artist, Stanley Brouwn. In his work, 
This Way Brouwn (1964), Brouwn walked the streets of Amsterdam and asked passers-by for directions and prompting the helpful strangers to draw their directions out. He collected a wide array of drawing. I reperformed this work as an arts-based research (Gauntlett 2007) project in contemporary conditions of Google Maps.

The directions I asked for were to and from iconic locations in these cities, such as public squares, prominent landmarks, busy food markets, central transportation stations, or popular museums and libraries. The encounters framed moments of spontaneous spatial sense-making through direction-giving and on-the-spot navigation. The drawings were ad-hoc in their rendering, as were the decisions to guide me to my destination. I did not collect identifiable data related to the informants. Instead, the informant is framed as a generalizable 'user' reflective the prototypical subject employed by the tech giants of Silicon Valley. The research reflects the observed actions of wayfinding set in relation to the technological speak of a Google Maps ideal user.

At the end of data collection, I had a visual data set of 220 unique drawings of city streets, 55 per city. Over the course of data collection and analysis, I noted how and when digital maps, specifically Google Maps, were used to mediate the process of giving directions during the encounters. The empirical research was then mapped onto a discourse analysis of Google's own discursive framing of Google Maps to look at how street-level wayfinding compares to the rhetoric.

\section{Analysis}

I paired Tomasz Konecki's (2011) model of visual grounded theory (VGT) with Adele's Clarke Situational Analysis (2005) to frame my analysis. VGT emphasizes the uniqueness of visual data to the analysis process as a site of interpretation. VGT is particularly useful for visual projects that do not use consistent practices of drawing elicitation such as my own (with only $10 \%$ of the drawings I collected come with a related interview). Instead of having the informant speak directly to their drawing, the emphasis of VGT is on multi-modality and looking across different types of data gathered during the initial stages of collection. Situational Analysis is a way to account the messy complexities of a situation based on the complex relations among the human and non-human areas and "the arenas of commitment within which they are engaged." (Clarke, 2004).

To help think through some of the early findings, I turned my attain to the rhetorical framing Google Maps deploys within The Google webpage, The Google official blog titled, The Keyword, The Google Maps Platform webpage, and Google's Annual Developers Conference, $\mathrm{I} / \mathrm{O}-$ and the presentations uploaded to YouTube. What values are reflected in the language and rhetorical framing of Google Maps by Google Maps? My intention was to look at the relations that run across and between the human and non-human in the wayfinding situation - how the environment, the technology, and the social are part of the wayfinding practice.

\section{Findings}


When looking at Google Maps' discursive maneuvers, I note the repeated focus on the imperatives to "discover" and "explore." I noted when emphasis was placed on acts of personalization by way of "your world" and "your plans." Explore is a means to consumption framed by locating different restaurants, coffee, bars, and hotels, for example. Navigation is a means to the 'best route' finding the fastest way, avoiding traffic, as well as avoiding the 'speed traps' that might impede speed. Google Maps' discursive maneuvers promotes reliability, ease of use, exploration, and experience as central to practices of wayfinding.

Returning to the street-level encounter of my empirical research, when asking for directions, Google was often used to find what was referred to as 'the best' way and 'the fastest' route. It was used to double check. To show me the way. But at the same time, it was difficult to use. The translation of information from screen to ground was not always straight forward and assigning the platform the task of 'doing the thinking' or providing confirmation when planning routes. Google Maps was also used when participants first noted they were unfamiliar with the area but were able to give directions based on the search function of Google suggesting a spatial command or even a claim to space that may otherwise have been unknown. The discursive and empirical findings intersect to create a conceptual framework to assess orientations towards the map.

\section{Contributions}

The project brings into question processes of wayfinding, spontaneous drawing, geographical information systems, and digital mapping broadly. The paper's focus is to reflect on the intersections and the divergences between the Google Maps rhetoric and the types of street-level observed during the research. Given the scale at which visual information is now transmitted, there is a need to study visual information as a form of knowledge production. Consulting mapping applications for route directions, as well as tagging and sharing locations, are now everyday occurrences. According to Google, one in every five internet searches is locationrelated. That number grows to one in three for mobile searches. Broadly speaking, location plays a central role in how information is organized and navigated online (De Souza e Silva \& Gordon 2011) and Google Maps is now the familiar interface to access not just place-based information but to spatialize and locate search queries. Issues of contemporary wayfinding deal with a range of urgent overlapping information issues, particularly the spatiotemporal information grounds of sense making but through a critical lens that troubles normative understandings of everyday information experiences. Instead, wayfinding is part of a complicated set of relations that are at the intersection of the material conditions and the subjective experience.

\section{References}

Ahmed, S. (2006). Queer Phenomenology. Durham, NC: Duke University Press. Ahmed, S. (2010). The Promise of Happiness. Durham, NC: Duke University Press. Arthurs, P. \& Passini, R. (1992). Wayfinding: People, Signs, and Architecture. New York: NY: McCraw-Hill.

Björneborn L (2008) Serendipity dimensions and users' information behavior in the physical library interface. Information Research, 13(4): paper 370.

Brouwn, S. (1961). This Way Brouwn. [Collection of drawings from public performances in 
Amsterdam]. MOMA. New York, NY.

Clarke, A. (2005). Situational analysis: Grounded theory after the postmodern turn. Thousand Oaks, CA: Sage.

Cresswell, T. (2006). On the Move: Mobility I the Modern Western World. New York, NY: Routledge.

Cresswell, T. (2011). Mobilities I: Catching up. Progress in Human Geography, 35 (4), 550-558.

Dervin, B. (1983). An overview of sense-making research: concepts, methods and results to date, International Communication Association Annual Meeting, Dallas, TX.

Dervin, B. (2003). Information as non-sense; information as sense: The communication technology connection. In B. Dervin, L. Foreman-Wernet, \& E. Launterbach (Eds.), Sense-making methodology reader: Selected writings of Brenda Dervin. Cresskill, NJ: Hampton Press, 293-308.

De Souza e Silva, A., \& Frith, J. (2010). Locative mobile social networks: Mapping communication and location in urban spaces. Mobilities, 5(4), 485-505.

De Souza e Silva, A. and Gordon, E. (2011). Net locality: Why location matters in a networked world. Chichester, UK: Wiley-Blackwell Publishing.

Falk \& Dierking (2016).The Museum Experience Revisited. London, UK: Routledge.

Gauntlett, D. (2007). Creative Explorations: New approaches to identities and audiences. London, UK: Routledge.

Hannam, K.; Sheller, M.; \& Urry, J. (2006). Mobilities, immobilities and moorings. Mobilities, 1(1), 1-22.

Hawkins, A.J. (Decebmer, 2017). This deep dive into Google Maps is fascinating: Google Maps is more powerful than you know. Verge. Retrieved from: https://www.theverge.com/2017/12/24/16801334/google-maps-justin-obeirnecartographer-apple-waymo

Konecki, K.T. (2011). Visual Grounded Theory: A methodological outline and examples from empirical work. Revija Za Socilologiju, 41(2) 131-160.

Mandel, L. H. (2010). Toward an understanding of library patron wayfinding: Observing patrons' entry routes in a public library. Library and Information Science Research, 32, 116-130.

Mandel, L. H. (2012). Lost in the labyrinthine library: A multi-method case study investigating public library user wayfinding behavior. (Doctoral dissertation).

Mandel LH (2013) Finding their way: How public library users wayfind. Library and Information Science Research, 35(4): 264-271.

Mandel, L.H. (2018). Understanding and describing users' wayfinding behaviour in public library facilities. Journal of Librarianship and Information Science, 50(1), 23-33.

Massey, D.B. (2005). For Space. Thousand Oaks, CA: Sage Publications.

Mattern, S. (2015). Deep Matting the Media City. Minneapolis, MN: University of Minnesota Press.

Mattern, S. (2017). Code + Clay...Data + Dirt: Five Thousand Years of Urban Media. Minneapolis, MN: University of Minnesota Press.

Noble, S. U. (2011). Geographic information systems: A critical look at the commercialization of public information. Human Geography: A New Radical Journal, 4(3), 88-105. 
Noble, S. U. and Roberts, S. T. (2015). Through Google colored glass(es): Emotion, class and wearables as commodity and control. In Emotions, Technology and Design, Eds. Safiya Umoja Noble and Sharon Tettegah. Elsevier; UK.

Noble, S. (2018). Algorithms of Oppression: How Search Engines Reinforce Racism. New York, New York: University of New York Press.

Roberts, S.T. (2018). Digital detritus: 'Error' and the logic of opacity in social media content moderation. First Monday, 23(3).

Savolainen, R. (1998). Seeking and using information from the Internet. The context of non-work use. In Exploring the Contexts of Information Behaviour, Proceedings of the 2nd International Conference on Research in Information Needs, Seeking and Use in Different Contexts, Sheffield, UK, August 13-15. Wilson, T., Allen, D., Eds.; Taylor Graham: London, 1998; 356-370.

Savolainen, R. (2008), Everyday Information Practices: A Social Phenomenological Perspective. Lanham, MD: Scarecrow Press.

Sharma, S. (2012). It Changes Space and Time! Introducing Power-Chronography. In Communication Matters: Materialist Approaches to Media, Mobility and Networks, edited by Jeremy Packer and Stephen B. Crofts Wiley, 66-77. London, UK: Routledge.

Sharma, S. (2014). In the Meantime. Durham, NC: Duke University Press.

Sheller, M., \& Urry, J. (2006). The new mobilities paradigm. Environment and Planning A. 38(2): 207-226.

Tuck, E., \& McKenzie, M. (2015). Place in Research: Theory, Methodology, and Methods. New York, NY: Routeledge.

Urry, J., 2007. Mobilities. Cambridge: Polity. 